\title{
Proteomic Profiling and Neurodegeneration in West-Nile-Virus-Infected Neurons
}

\author{
V. Dhingra, ${ }^{1}$ Q. Li, ${ }^{1}$ A. B. Allison, ${ }^{2}$ D. E. Stallknecht, ${ }^{2}$ and Z. F. Fu ${ }^{1,2}$ \\ ${ }^{1}$ Department of Pathology, College of Veterinary Medicine, University of Georgia, Athens, GA 30602, USA \\ ${ }^{2}$ Department of Infectious Diseases, College of Veterinary Medicine, University of Georgia, Athens, GA 30602, USA
}

Received 4 October 2004; revised 9 February 2005; accepted 14 February 2005

\begin{abstract}
West Nile virus, a mosquito-borne flavivirus, is a human, equine, and avian pathogen. High-resolution two-dimensional differentialgel electrophoresis (2D-DIGE) was used to characterize protein expression in primary rat neurons and to examine the proteomic profiling to understand the pathogenesis of West-Nile-associated meningoencephalitis. Three $\mathrm{pH}$ ranges, 3-10, 4-7, and 5-6, were used to analyze the protein spots. The proteins are labeled with fluorescent dyes Cy3 and Cy5 before being separated on the basis of charge and size respectively on a two-dimensional platform. About 55 proteins showed altered expression levels. These were then subsequently digested and identified by matrix-assisted laser desorption/ionization time-of-flight mass spectrometry (MALDITOF MS) analysis using peptide mass fingerprinting and database searching. These cellular proteins could represent distinct roles during infection related to apoptosis. Our findings show that two-dimensional differential gel electrophoresis combined with mass spectrometry is a powerful approach that permits the identification of proteins whose expression was altered due to West Nile virus infection.
\end{abstract}

\section{INTRODUCTION}

West Nile virus (WNV) is a flavivirus that is transmitted by mosquitoes and causes fever, encephalitis, and death in birds and mammals, most notably humans and horses [1]. The virus was originally isolated in 1937 from a febrile human who resided in the West Nile district of Uganda [2]. It is distributed extensively throughout Africa, the Middle East, parts of Europe, Western Russia, South Western Asia, and Australia [3]. In the summer of 1999, WNV appeared for the first time in North America $[4,5]$. Within a short period of five years, WNV has spread to almost all the contiguous states in the United States and parts of Canada [6]. In general, WNV causes fever and occasionally meningoencephalitis (WNME) $[7,8]$. This later condition can be fatal, especially in elderly people [9]. WNV infection can cause paralysis by destroying neurons in the anterior horn of spinal cord [10]. This loss of specific neuronal population might actually represent the anatomical and functional substrate of many symptoms associated with WNV infections. Pathophysiological

Correspondence and reprint requests to Z. F. Fu, Department of Pathology, College of Veterinary Medicine, University of Georgia, Athens, GA 30602, USA, E-mail: zhenfu@vet.uga.edu

This is an open access article distributed under the Creative Commons Attribution License which permits unrestricted use, distribution, and reproduction in any medium, provided the original work is properly cited. mechanisms and molecular pathways of WNME have yet to be resolved. There are various hypotheses elucidating the mode of neuronal injury following WNV infection $[11,12,13]$. However, they still remain controversial.

Studies measuring changes in the expression of multiple proteins promise to provide a powerful strategy for characterizing complete pathophysiologic processes and designing novel drug therapies. To date, the only available and most consistently successful approach to identify proteins and their post-translational modification is twodimensional (2D) electrophoresis. It is a long established technology whereby proteins are separated according to their molecular weight and isoelectric point. This can be used to characterize proteins detected as spots on gels. Two-dimensional electrophoresis has progressed significantly since it was first described by O'Farrell in 1975 [14] with innovations such as precast immobilized $\mathrm{pH}$ gradient gels to aid first-dimension separation and highly sensitive and linear sensitive fluorescent dyes that allow both visualization and quantitation of separated proteins. Conventional two-dimensional (2D) methods rely on comparing profiles from at least two gels. Unfortunately, this can lead to problems in reproducibility, as no two gels can be identical due to differences in gel composition, electric and $\mathrm{pH}$ fields, and thermal fluctuations. Significant improvements have been made in 2D technology with the development of fluorescence $2 \mathrm{D}$ differential gel electrophoresis (2D-DIGE) technology, the principle of which was originally described by Ünlü et al, 1997 [15]. 


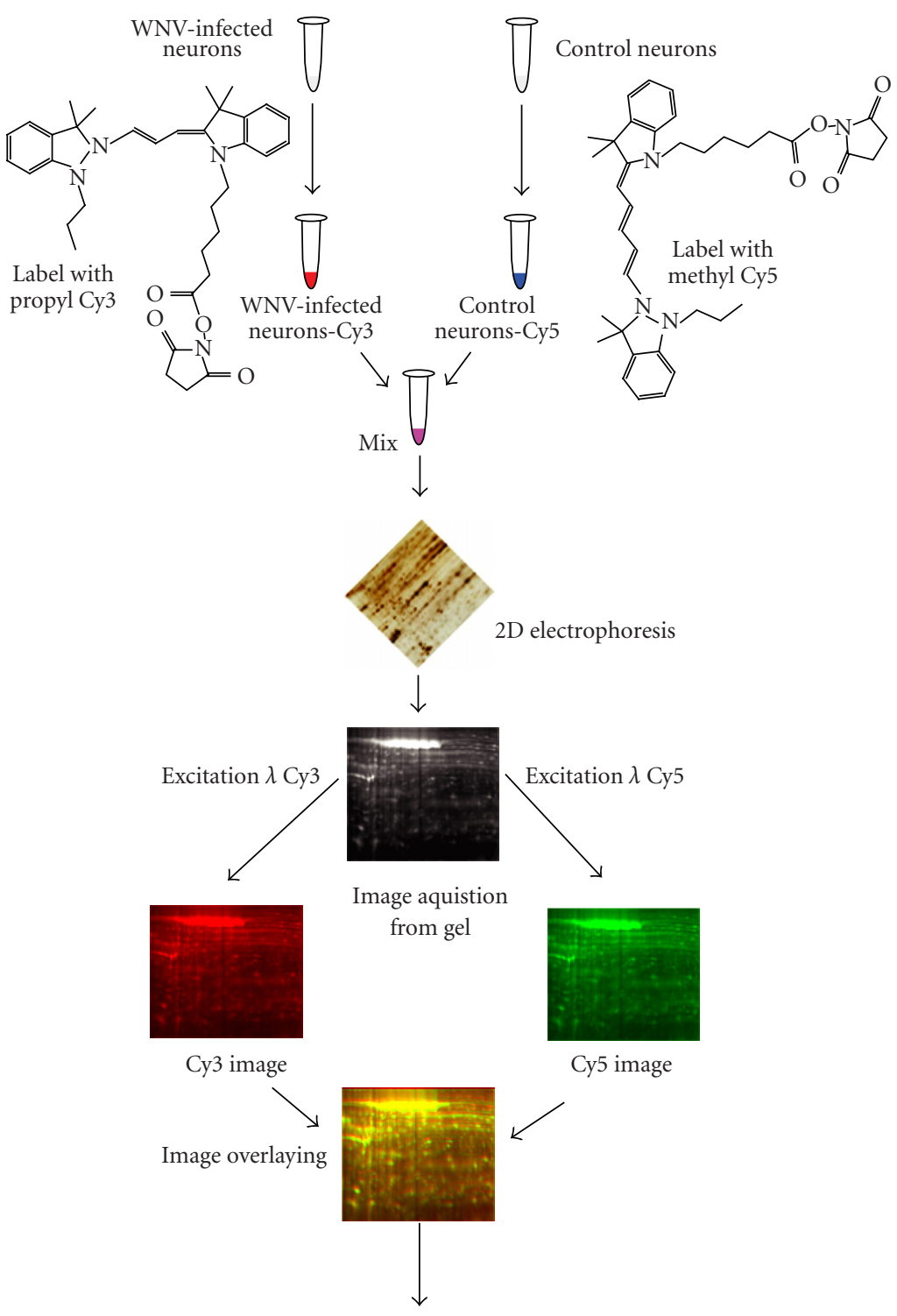

Image analysis

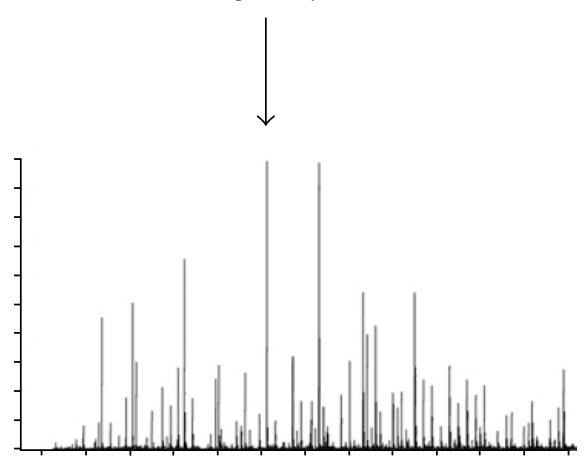

FIgure 1. Flow chart of 2D-DIGE analysis. Proteins from WNV-infected neurons and respective controls are labeled with Cy3 and Cy5 dyes. These labeled samples are then mixed and applied to a 2D gel. The resulting protein pattern is compared and analyzed for differential protein expression. Proteins can be identified by mass spectrometry. (Modified from Van den Berg and Arckens, 2003.)

Proteins are first pre-electrophoretically labeled with one of the three spectrally resolvable fluorescent cyanine dyes (Figure 1). This improves the sensitivity and dynamic range of protein detection. Molecular weight and charged matched cyanine dyes enable multiplex labeling with different samples run on the same gel [16]. 
To our knowledge, this is the first comprehensive study to evaluate protein expressional changes in WestNile-virus-infected neurons. We used proteomic fractionation by $2 \mathrm{D}$ electrophoresis, $2 \mathrm{D}$ differential gel electrophoresis (2D-DIGE), followed by mass spectrometry to evaluate and identify an array of proteins that may be intimately associated with the process of neuronal cell death due to WNV infection.

\section{MATERIALS AND METHODS}

\section{Reagents}

N-hydroxy succinimide ester Cy3 and Cy5 dyes as well as all the reagents for running $2 \mathrm{D}$ electrophoresis were purchased from Amersham Biosciences (Piscataway NJ); Sypro Ruby gel stain was purchased from Molecular Probes (Eugene, OR).

\section{Primary culture of rat cortical neurons}

Establishment of the cultures of rat (Sprague Dawley) embryonic (18 days) cortical neurons was based on the methods of Dravid and Murray [17] and Adamec et al [18], with some modifications. Briefly, pregnant mice were euthanized by $\mathrm{CO}_{2}$ asphyxiation, and embryos were removed under sterile conditions. Neocortices were collected, stripped of meninges, minced by trituration with a Pasteur pipette and treated with trypsin for $20 \mathrm{~min}$ utes in a $37^{\circ} \mathrm{C}$ water bath. The cells were then dissociated by two successive trituration and sedimentation steps in an isolation buffer containing soybean trypsin inhibitor and DNase. The cells were then centrifuged and resuspended in neurobasal medium supplemented with B27 (1X), glutamine $(2 \mathrm{mM})$, glutamate $(25 \mu \mathrm{M})$, penicillin $(100 \mathrm{U} / \mathrm{mL})$, streptomycin $(100 \mathrm{~g} / \mathrm{mL})$, fetal calf serum $(1 \%)$, horse serum $(1 \%)$, and plated at the density of approximately $8 \times 10^{5}$ cells $/ \mathrm{mL}$ on polylysine- $(50 \mathrm{~g} / \mathrm{mL})$ precoated glass cover slips (diameter $12 \mathrm{~mm}$ ) in 12 -well plates, or approximately $2.25 \times 10^{6} \mathrm{cells} / \mathrm{mL}$ on polylysineprecoated 6-well plates. The cultures were maintained in a humidified atmosphere of $5 \% \mathrm{CO}_{2} / 5 \%$ air at $37^{\circ} \mathrm{C}$ in a tissue culture incubator. Ara-c $(5 \mu \mathrm{M})$ was added at 48 hours after plating to prevent the proliferation of nonneuronal cells. Half of the medium was changed to fresh Neurobasal / B27 four days after plating and subsequently once a week.

\section{Virus}

Neuronal cells were infected with WNV strain DES 160-02 that was isolated from a dead American crow (Corvus brachyrhynchos) from Georgia, USA, in 2002. It has been passaged twice in African green monkey kidney cells (Vero Middle America research Unit (MARU)) for initial isolation and generation of stock virus. Virus titers were determined in Vero MARU cells using the procedure as described in [19]. Primary neurons were infected with WNV at a multiplicity of infection (MOI) of 5 plaque forming units (pfu) per cell. At day 5 post infection (p.i.), the cells were fixed with $10 \%$ neutral buffered formalin and stained with $0.25 \%$ crystal violet.

\section{Immunocytochemistry}

For detection of virus infection, expression of microtubulin-associated protein (MAP2), and apoptosis, primary neuronal cultures on glass cover slips were fixed in paraformaldehyde (4\%) in PBS overnight at room temperature, permeabilized by 15 -minute incubation with Triton X-100 (0.1\%) in PBS, and subsequently blocked for 30 minutes with goat serum (1\%). Primary antibodies were incubated overnight at $4{ }^{\circ} \mathrm{C}$ in a hybridization chamber. Virus antigen was detected using an affinitypurified rabbit anti-WNV antibody directed against a peptide corresponding to amino acids $235-250$ of the envelope protein. MAP2 was detected using an anti-MAP2 antibody [20]. For both virus infection and MAP2 expression, the secondary antibody used was goat anti-rabbit IgG tagged with Alexa Fluor 488 [21]. Apoptosis was detected by the terminal deoxynucleotidyl transferasemediated dUTP nick end labeling (TUNEL) assay using the Fluorescent FragELTM DNA fragmentation Detection Kit (Oncogene) according to manufacture's instructions.

\section{Sample preparation for $2 D$ analysis}

The neuronal monolayer was rinsed once with $1 \mathrm{X}$ phosphate buffer saline (PBS), $\mathrm{pH}$ 7.4, to remove the cell culture medium. The cells were lysed in buffer, containing $9 \mathrm{M}$ Urea, $10 \mathrm{mM}$ DTT, $30 \mathrm{mM}$ Tris, $4 \%$ CHAPS (3-[(3-cholamidopropyl)dimethylammonio]-1propanesulfonate) and harvested using a cell scraper. The cells were sedimented by centrifugation at $2000 \mathrm{xg}$. After centrifugation, the cells were disrupted by ultrasonication (Braunsonic 300s) twice for 15 seconds on ice. The resulting homogenate was centrifuged twice for 30 minutes at $12000 \mathrm{xg}$. All the steps were carried out at $4{ }^{\circ} \mathrm{C}$. Protein concentration was measured by Bradford method using bovine serum albumin as a standard [22].

\section{Cy dye labeling}

WNV-infected neuronal protein lysates and control lysates were labeled using the fluorescent cyanine dyes (Cy3 and $\mathrm{Cy} 5)$ according to the manufacturer's recommended protocols. Protein $(50 \mu \mathrm{g})$ from cell lysates was labeled with $400 \mathrm{pmol}$ of amine reactive cyanine dyes, that is, Cy3 or Cy5 N-hydroxysuccinamide (NHS) ester DIGE dyes (Amersham Biosciences), freshly dissolved in anhydrous dimethyl formamide. No primary amines, DTT, or carrier ampholytes were included in the lysis buffer as such components could potentially react with the NHS esters of the cyanine dyes. The labeling mixture was incubated on ice in the dark for 30 minutes. The reaction was quenched by addition of $10 \mathrm{nmol}$ of lysine followed by incubation on ice for another 10 minutes. Equal volumes of $2 \mathrm{X}$ sample buffer containing $7 \mathrm{M}$ Urea, $2 \mathrm{M}$ thiourea, $4 \% \mathrm{w} / \mathrm{v}$ CHAPS, $65 \mathrm{mM}$ DTT, and 2\% v/v immobiline $\mathrm{pH}$ gradient (IPG) buffer were added to each of the labeled protein samples, and the two samples were mixed prior to isoelectric focusing (IEF) on Immobiline IPG strips. 


\section{Two-dimensional gel electrophoresis}

First-dimension separation was carried out by using the immobiline dry strips $\mathrm{pH} 4-7$ (linear). The strips were rehydrated in a rehydration solution containing $7 \mathrm{M}$ Urea, $2 \mathrm{M}$ thiourea, 2\% CHAPS, $30 \mathrm{mM}$ Tris, 2\% IPG buffer, $28 \mathrm{mM}$ DTT, and trace of bromophenol blue, overlaid with $3 \mathrm{~mL}$ dry strip cover fluid, in an immobiline dry strip reswelling tray. The samples were applied at the basic end of the IPG strip using a cup-loading technique. IEF was carried out on a multiphor electrophoresis unit consisting of five phases of stepped voltages from 500 to $3500 \mathrm{~V}$ with total focusing of $48 \mathrm{kVh}$. Focusing started at $500 \mathrm{~V}$ for 4 hours at $15^{\circ} \mathrm{C}$ and then continued at $3500 \mathrm{~V}$ for 12 hours. The narrow $\mathrm{pH}$ range IPG strips were focused to $70 \mathrm{kVh}$.

Prior to the second dimension, strips were equilibrated in buffer containing $6 \mathrm{M}$ urea, $1 \% \mathrm{w} / \mathrm{v}$ sodium dodecyl sulfate (SDS), 30\% v/v glycerol, $100 \mathrm{mM}$ Tris, $\mathrm{pH}$ 6.8 , reduced with $2 \%(\mathrm{w} / \mathrm{v})$ DTT, and subsequently alkylated with $2.5 \%(\mathrm{w} / \mathrm{v})$ iodoacetamide. After equilibration, proteins were separated on second-dimension separation on a $10 \%$ gel, $20 \mathrm{~cm} \times 20 \mathrm{~cm}$, at $30 \mathrm{~mA}$ constant [23], in a BioRad Protean II xi system (Bio-Rad Laboratories, Hercules, Calif). The strips were sealed on the top of the gels using a sealing solution ( $1 \%$ agarose, $0.5 \%$ SDS, $0.5 \mathrm{M}$ Tris- $\mathrm{HCl})$. The run was completed once the bromophenol blue reached the bottom or run of the gel.

\section{Image analysis}

The Cy3 gel images were scanned on the Typhoon 9400 Variable Mode Imager (Amersham Biosciences) at an excitation wavelength of $540 / 25 \mathrm{~nm}$ (maxima/bandwidth) and at an emission wavelength of $590 / 30 \mathrm{~nm}$, while the Cy5 gel images were scanned at an excitation wavelength of $620 / 30 \mathrm{~nm}$ and at an emission wavelength of $680 / 30 \mathrm{~nm}$. Gel images were converted to 16-bit TIFF files and processed in DeCyder V3.0 (Amersham Biosciences). The spots on the gel were codetected automatically as DIGE image pairs, which were intrinsically linking a sample to its in-gel standard. Matching between gels was then performed utilizing the in-gel standard from each image pair. The experimental setup and relationship between samples were assigned in DeCyder, a 2D analysis software platform designed specially for DIGE. Each individual Cy5 gel image was assigned an experimental condition as either control or infected, and all Cy3 images were assigned as the standard.

Alternatively, in order to obtain a visual appreciation of the differences in fluorescent spot intensity, falsecolored gel images were constructed using the protein patterns originating from the Cy3- and Cy5-labeled samples present in the same gel. For this purpose, signal intensities of both images were adjusted using Adobe Photoshop 7 (Adobe Software, San Jose, Calif), to correct for uneven fluorescence yields. The gray-scale Cy3 and Cy5 images were false-colored in red and green, respectively. The overlay image showed yellow spots where proteins were present in equal amounts and red or green spots indicating proteins with a higher expression in the Cy3- or Cy5labelled experimental condition. Proteins were believed to be differentially expressed when they were visible as red or green spots, depending on the experimental condition [24]. After 2D-DIGE imaging and image analysis, the protein spot pattern was visualized by Sypro Ruby stain. The gels are then stored in $1 \%$ acetic acid at $4{ }^{\circ} \mathrm{C}$ until spot excision.

\section{Peptide mass fingerprinting}

For peptide mass fingerprinting, in-gel digestion was either performed manually or by using an automated protein digestion system [Ettan digester (Amersham Biosciences)] according to the manufacturer's protocol [25]. In brief, the gel plugs were washed with $50 \mathrm{mM}$ ammonium bicarbonate, then with $50 \% \mathrm{v} / \mathrm{v}$ acetonitrile in water followed by $100 \% \mathrm{v} / \mathrm{v}$ acetonitrile for dehydration [25]. Following overnight digestion with trypsin (Promega, Madison, Wis) in $50 \mathrm{mM}$ ammonium bicarbonate ( $\mathrm{pH}$ 8.0) at room temperature, peptides were extracted using sequential steps of $0.2 \% \mathrm{v} / \mathrm{v}$ TFA in water, followed by $50 \% \mathrm{v} / \mathrm{v}$ acetonitrile in $0.1 \% \mathrm{v} / \mathrm{v}$ TFA. Some of the peptide extracts were desalted using ZipTips C18 (Millipore, Bedford, MA) according to the manufacturer's protocol. The peptides were eluted with $5 \mu \mathrm{L}$ of $50 \% \mathrm{v} / \mathrm{v}$ acetonitrile and $0.1 \% \mathrm{v} / \mathrm{v}$ TFA. The peptide extracts were used for MALDI-TOF protein identification [26]. The proteins used as controls were conalbumin type I, bovine serum albumin, carbonic anhydrase, trypsin inhibitor, and rabbit muscle glyceraldehydes 3-phosphate dehydrogenase (Bio-Rad, catlog no 161-3020). All standard proteins were identified in every run with $\sim 95 \%$ accuracy.

\section{Database analysis}

Protein identification was performed using the measured monoisotopic masses of peptides and analyzed using worldwide web (WWW) search programs such as MS-FIT provided by UCFS (http://prospector.ucsf.edu/ ucsfhtml4.0/msfit.htm), PROFOUND provided by Rockefeller University (version 4.7.0) (http://prowl. rockefeller.edu/profound_bin/WebProFound.exe), or MASCOT (http://www.matrixscience.com) using National Center for Biotechnology (NCBI) database. These programs calculate the likelihood of correct identification based on the theoretical number of peptides in a trypsin digest of a given protein and number of peptides matched [27]. A mass tolerance of $0.02 \mathrm{~d}$ was used for masses measured in reflector mode and mass tolerance of $0.1 \%$ was used for masses measured in linear mode. Acetylation of the Nterminus, alkylation of cysteine, and oxidation of methionine were considered as possible modifications.

\section{RESULTS AND DISCUSSION}

Understanding the complex changes taking place in biological systems or disease at the molecular level will 
eventually lead to a better understanding of the underlying mechanisms. The proteomics technology is conceptually well suited to describe the molecular anatomy of a system and its changes in levels of protein and their expression pattern [28]. In this work, two samples on each gel were differentially labeled with spectrally different fluorescent cyanine dyes, Cy3 and Cy5 (Figure 1). These dyes are approximately $500 \mathrm{~d}$ in molecular weight and are matched for charge and molecular weight, ensuring that the same protein will migrate to the same position on a $2 \mathrm{D}$ gel. These are $\mathrm{pH}$-insensitive, having no change in signal over wide $\mathrm{pH}$ range used during first-dimension (ie, IEF) separation. However, they have different emission and excitation wavelength $[15,29]$. The protein-dye labeling is done by a lysine labeling (minimal labeling) method, which labels the proteins via the epsilon amino group of lysine. Protein solution was cleaned of interfering substances (phenolic compounds, nucleic acids) by using a 2-D clean up kit (Amersham Biosciences) [30].

Two-dimensional profiles of primary neuronal lysates showed high-resolution separation of spots and low-stain background on silver stain (Figure 2). Protein spots that were either up- or downregulated were marked. We observed that most of the protein spots were between $150 \mathrm{kd}$ and $15 \mathrm{kd}$. Few high molecular weight proteins could be observed. This could be due to the limited ability of high molecular weight proteins to enter the first-dimension IPG gel. Protein spots that significantly increased or decreased in neurons infected with West Nile virus, when compared to control, were picked and analyzed. Three $\mathrm{pH}$ gradients, ranging from $\mathrm{pH} 3$ to $10, \mathrm{pH} 4$ to 7 , and $\mathrm{pH} 5$ to 6, were used to analyze the protein spots in two dimensions. Protein profiles at $\mathrm{pH} 3-10$ and $\mathrm{pH} 4-7$ showed that most of the changes (i.e., up- or downregulated) observed in WNV-infected neurons were within the $\mathrm{pH}$ range of 57 (Figure 2). Hence, we decided to investigate these proteins in more detail. This was done by using the 2D-DIGE technology at a narrow isoelectric focusing $\mathrm{pH}$ gradient of 5-6 to get a better resolution. Moreover, silver stain, though sensitive, does not have dynamic linearity and has a large protein-to-protein variability making quantification more difficult and less reproducible [31]. Also, at narrow $\mathrm{pH}$ ranges, we can load large amount of protein without affecting the resolution on the gel. Running both the samples on the same gel in DIGE refines the detection of changes of expression at the protein level. Variation in spot intensities (protein expression) due to experimental factors would be the same for each sample within the DIGE gel. DIGE, therefore, increases the confidence with which protein differences can be detected and quantified [32]. To assess the global changes in protein blueprint caused by Cy dye labeling, the same gel was also labeled by Sypro Ruby stain. The patterns of cyanine dyes and Sypro Ruby dye were very similar enabling accurate spot matching and picking. A total of 1548 spots were detected on the gel. Fifty-five gel plugs were picked from the gel and excised for trypsin digestion. A 2-mm spot picking head was used to pick spots from the gel. This allows picking

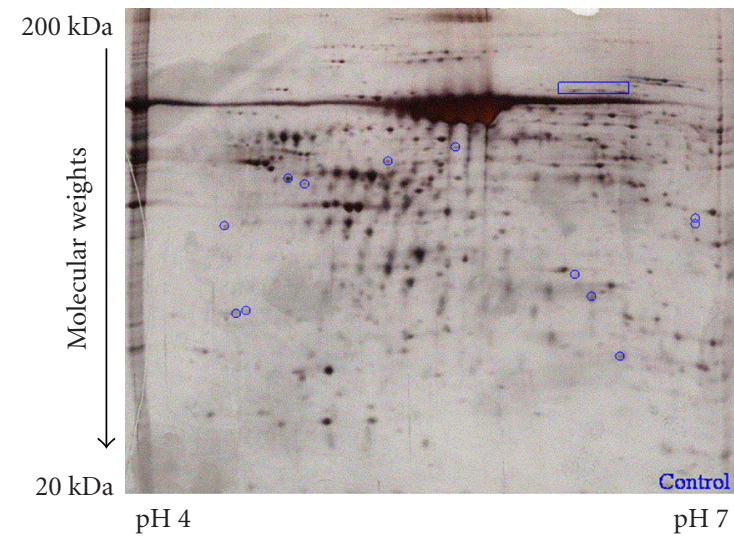

(a)

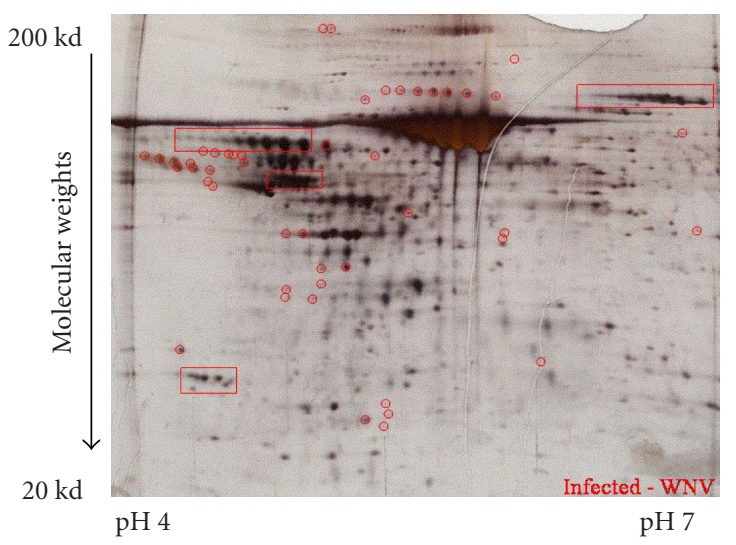

(b)

FIgURE 2. Silver-stained 2D gels in control and WNV-infected neurons. The $\mathrm{pH}$ range is $4-7$ and the molecular weight markers represent from $200 \mathrm{kd}$ to $20 \mathrm{kd}$ (top to bottom). The spots circled in (b) (infected-WNV) represent the protein expression that is upregulated and the spots in (a) (control) show the proteins that have been downregulated in WNV infected neurons.

from the central region of the spot, thereby minimizing cross-contamination of the neighboring spots. The digest was then used for MALDI-TOF MS analysis using peptide mass fingerprinting and database searching. Trypsin auto digestion peaks were used as internal calibrants.

Many spots were observed to be either up- or downregulated following WNV infection. A minimum of 20 matching peptides was used as a criterion for protein search. In most cases, a large number of matching peptides were found. In six cases, no identification was assigned due to either absence from the database or because the number of peptides generated was insufficient to warrant reliable identification. Quantitative analysis using DeCyder software showed 17 spots decreased in WNVinfected neuron culture at a $\mathrm{pH}$ range of 5-6 (Figure 3). Four of these spots were identified as Fyn-protooncogene, Coatomer protein complex, Ra1A-binding protein, and dihydropyrimidinase-related protein-2 (DRP-2). Thirtyeight proteins were observed to significantly increase in 


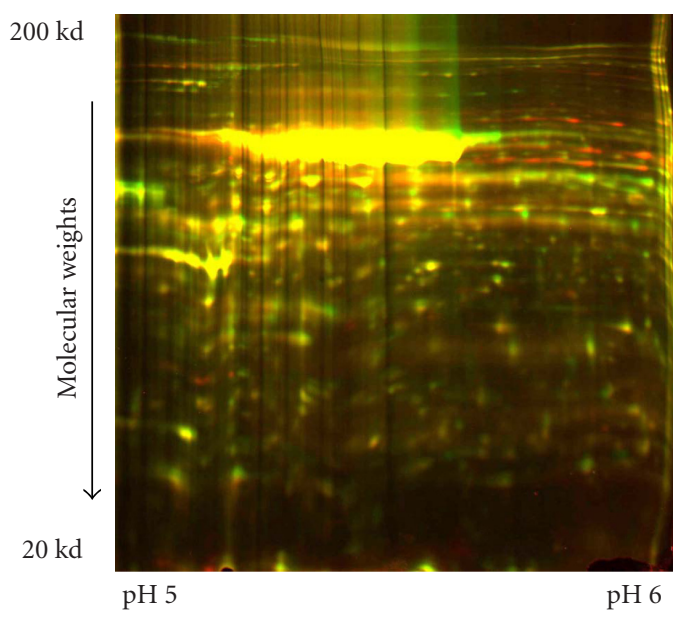

Figure 3. DIGE gel image of WNV-infected neurons and control (normal). WNV-infected neuronal protein and control neuronal protein are labeled with $\mathrm{Cy} 3$ and $\mathrm{Cy} 5$ respectively. The protein samples are mixed and run on an IPG strip of pH 5-6, separated on a $20 \mathrm{~cm} \times 20 \mathrm{~cm}$ gel. Spots in green are upregulated, while spots in red are downregulated in WNV-infected neurons. The gel is then stained with Sypro Ruby and spots are picked, digested, and identified using mass spectrometry.

WNV-infected neurons. Five of these spots were identified as Ras-GTPase-activating protein, SH3-domain-binding protein, Restin, $\beta$-amyloid peptide, and Ret finger protein (Table 1). The presence of SH3-domain-binding proteins and Ras-GTPase activating protein has been shown to be essential for the Ras signal transduction pathway [33]. It is also shown to be a target of caspases in spontaneous apoptosis of lung carcinoma cells in response to etoposide [34] indicating its role in cell cycle regulation and apoptosis. Restin shows a high homology with endostatin, and inhibits cell proliferation to induce cell apoptosis by binding to tropomyosin [35]. The presence of $\beta$-amyloid peptide is also suggestive of the induction of an apoptotic pathway in West Nile pathogenesis. Recently, Pereira et al (2004) pointed out the role that $\beta$ amyloid peptide might play in disrupting $\mathrm{Ca}^{2+}$ homeostasis, and this Alzhiemer's disease-associated amyloidogenic peptide has been reported to induce apoptotic death in cultured cells [36]. The Ret finger protein (RFP), a member of the tripartite motif family, is shown to induce apoptosis in human embryonic kidney cells [37]. RFP activates two distinct cell death pathways: one via a caspase pathway independent of mitochondrial events, and the other via a stress-activated MAP kinase pathway that involves JNK and p38 kinase. Neither of them alone is sufficient to initiate apoptosis, but both are required for RFPinduced apoptosis [37]. WNV has been shown to cause acute encephalitis and death in animals $[38,39]$. Parquet et al (2001) suggested that WNV induces cell death in $\mathrm{N} 2 \mathrm{a}$ neuroblastoma cells through an apoptotic mechanism [40]. We performed immunohistochemistry to confirm if the neuronal pathology and cell death is due to
Table 1. Proteins differentially expressed in response to WNV infection. Statistical analysis (Student's $t$ test) was done to determine the significance of the differential protein expression observed.

\begin{tabular}{lcc}
\hline Proteins identified & Fold change & $P \leq .05$ \\
\hline Fyn-protooncogene & $2.0 \downarrow$ & .01 \\
Coatomer protein complex & $4.2 \downarrow$ & .01 \\
Ral A-binding protein & $3.4 \downarrow$ & .01 \\
Dihydropyrimidinase- & $4.0 \downarrow$ & .003 \\
related protein-2 & $6.2 \uparrow$ & .02 \\
Ras-GTPase activating protein & $3.9 \uparrow$ & .008 \\
SH3-domain-binding protein & $4.6 \uparrow$ & .01 \\
Restin & $2.6 \uparrow$ & .003 \\
$\beta$-amyloid peptide & $4.8 \uparrow$ & .01 \\
Ret finger protein & &
\end{tabular}

WNV infection. We observed that WNV causes neuronal cell death in primary neurons (Figure 4). Dying neurons were identified by the fragmentation and shrinkage of the cell body with loss of nuclear structure, and neuronal processes. A TUNEL assay was performed to corroborate if the morphological changes observed in neurons infected with WNV were due to apoptosis. Fragmented and condensed nuclei were detected in WNV-infected neurons when compared to that of uninfected control (Figure 4). Similar observations were obtained by others when low virus titer inoculums were used $[41,42]$.

This study has unequivocally identified a large number of proteins that are regulated due to WNV infection of rat neurons. We have made an attempt to identify a few of them and further identification is under process. Neurodegenerative diseases are normally characterized by neuronal loss and cell death. A number of mechanisms appear to contribute towards the neurodegenerative process leading to neuronal apoptosis, toxicity, and unregulated proteolysis $[43,44,45]$. However, the mechanism of neuronal injury following WNV infection still remains contentious. Various groups have hypothesized the neuronal injury mechanisms to be either due to viral infection leading to apoptosis $[11,41]$ or by being the target to cytotoxic T lymphocytes [12, 46]. Chan et al (1989) suggested bystander injury as the cause of neuronal cell death [13]. Collectively, the data present here does give us an insight on the influence of apoptosis during West Nile pathogenesis. However, this may not be the only mechanism causing neuronal injury due to WNV infection. Further studies are required to investigate the changes in protein profile occurring in earlier events after West Nile virus infection. This can be achieved by carrying out time course studies on the protein profiles ranging from day 1 to day 5 post infections. To our knowledge, this is the first proteomic study using 2D-DIGE and MS to reveal the complex picture of protein expression and during WNV infection. However, this is a preliminary study of proteomic analysis and many questions remain unresolved. Studies investigating more $\mathrm{pH}$ ranges (single $\mathrm{pH}$ ranges) 

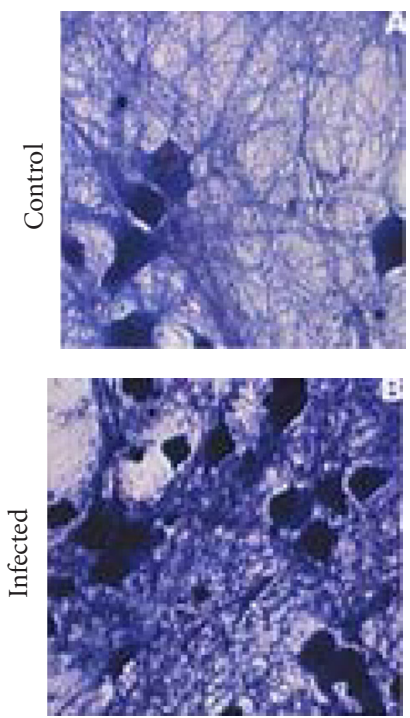

Crystal violet staining
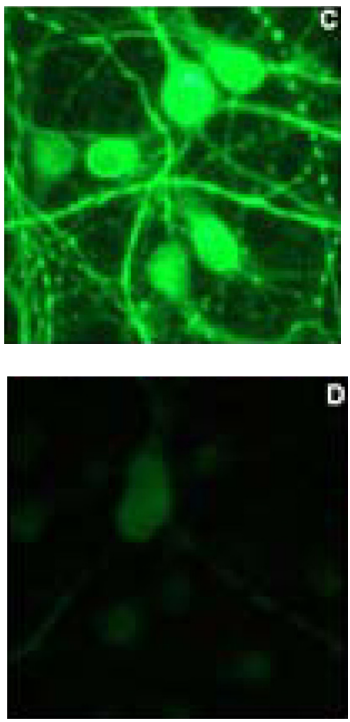

MAP2
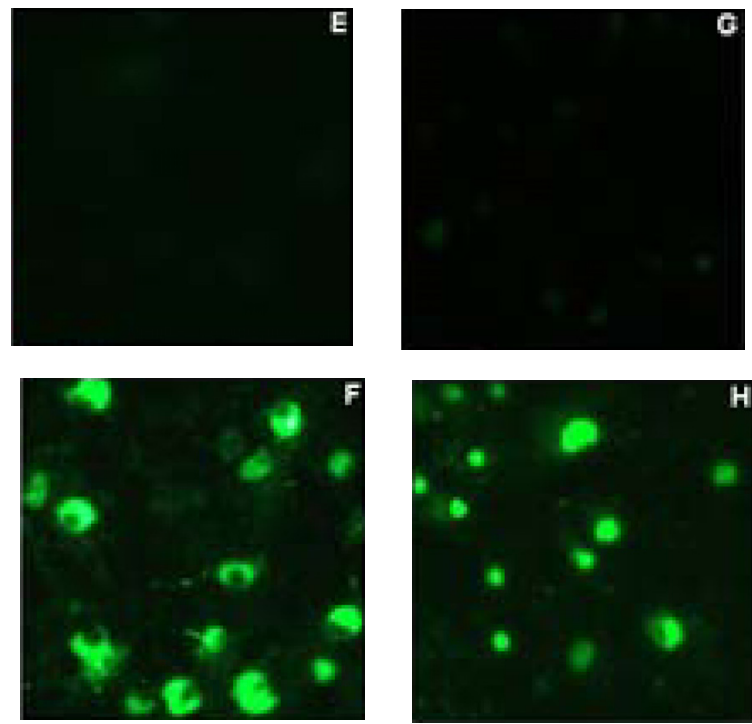

Viral antigen

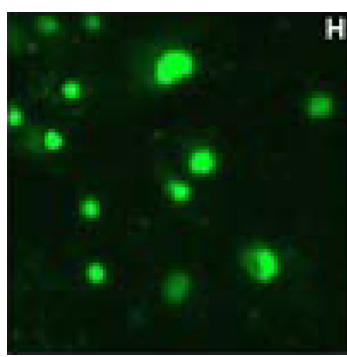

TUNEL

Figure 4. Crystal violet staining (A, B), MAP2 staining (C, D), WNV antigen staining (E, F), and TUNEL assay (G, H) of primary culture of rat cortical neurons. Uninfected control neurons morphologically look normal, with thick processes among neuronal bodies (A), while infected neurons show necrotic and apoptotic characteristics, including nuclear condensation, fragmentation, with most processes dissolved (B); WNV viral antigen staining shows bright cytoplasmic fluorescence in infected neurons (F), with control cells negative (E). In TUNEL analysis, control neurons (G) look normal, while infected neurons (H) show fragmented and condensed nuclei characteristic of cells undergoing apoptosis.

would be needed to better resolve the proteins. However, this report shows that using 2D-DIGE technology, one can efficiently process samples and apply these methods for clinical applications. The combination of twodimensional electrophoresis and multiplexing with Cyanine dyes provides a new approach to explore and understand the molecular basis of complex pathophysiological mechanisms associated with WNV infections and other neurodegenerative diseases.

\section{REFERENCES}

[1] Kramer LD, Bernard KA. West Nile virus infection in birds and mammals. Ann N Y Acad Sci. 2001;951:8493.

[2] Smithburn KC, Hughes TP, Burke AW, Paul JH. A neurotropic virus isolated from the blood of a native of Uganda. Am J Trop Med Hyg. 1940;20:471-492.

[3] Campbell GL, Marfin AA, Lanciotti RS, Gubler DJ. West Nile virus. Lancet Infect Dis. 2002;2(9):519529.

[4] Anderson JF, Andreadis TG, Vossbrinck CR, et al. Isolation of West Nile virus from mosquitoes, crows, and a Cooper's hawk in Connecticut. Science. 1999;286(5448):2331-2333.

[5] Lanciotti RS, Roehrig JT, Deubel V, et al. Origin of the West Nile virus responsible for an outbreak of encephalitis in the northeastern United States. Science. 1999;286(5448):2333-2337.

[6] CDC. West Nile virus activity-United States. Morb Mortal Wkly Rep. 2003;52:1160.
[7] George S, Gourie-Devi M, Rao JA, Prasad SR, Pavri KM. Isolation of West Nile virus from the brains of children who had died of encephalitis. Bull World Health Organ. 1984;62(6):879-882.

[8] Adelman RA, Membreno JH, Afshari NA, Stoessel KM. West Nile virus chorioretinitis. Retina. 2003;23(1):100-101.

[9] Chowers MY, Lang R, Nassar F, et al. Clinical characteristics of the West Nile fever outbreak, Israel, 2000. Emerg Infect Dis. 2001;7(4):675-678.

[10] Leis AA, Stokic DS, Webb RM, Slavinski SA, Fratkin J. Clinical spectrum of muscle weakness in human West Nile virus infection. Muscle Nerve. 2003;28(3):302-308.

[11] Prikhod'ko GG, Prikhod'ko EA, Pletnev AG, Cohen JI. Langat flavivirus protease NS3 binds caspase8 and induces apoptosis. J Virol. 2002;76(11):57015710.

[12] Kesson AM, King NJ. Transcriptional regulation of major histocompatibility complex class I by flavivirus West Nile is dependent on NF-kappaB activation. J Infect Dis. 2001;184(8):947-954.

[13] Chan WL, Javanovic T, Lukic ML. Infiltration of immune $\mathrm{T}$ cells in the brain of mice with herpes simplex virus-induced encephalitis. J Neuroimmunol. 1989;23(3):195-201.

[14] O'Farrell PH. High resolution two-dimensional electrophoresis of proteins. $J$ Biol Chem. 1975;250(10):4007-4021.

[15] Ünlü M, Morgan ME, Minden JS. Difference gel electrophoresis: a single gel method for 
detecting changes in protein extracts. Electrophoresis. 1997;18(11):2071-2077.

[16] Yan JX, Devenish AT, Wait R, Stone T, Lewis S, Fowler S. Fluorescence two-dimensional difference gel electrophoresis and mass spectrometry based proteomic analysis of Escherichia coli. Proteomics. 2002;2(12):1682-1698.

[17] Dravid SM, Murray TF. Spontaneous synchronized calcium oscillations in neocortical neurons in the presence of physiological $[\mathrm{Mg}(2+)]$ : involvement of AMPA/kainate and metabotropic glutamate receptors. Brain Res. 2004;1006(1):8-17.

[18] Adamec E, Yang F, Cole GM, Nixon RA. Multiplelabel immunocytochemistry for the evaluation of nature of cell death in experimental models of neurodegeneration. Brain Res Brain Res Protoc. 2001;7(3):193-202.

[19] Payment P, Trudel M. Methods and Techniques in Virology. New York, NY: Marcel Dekker; 1993.

[20] Marx CE, Jarskog LF, Lauder JM, Lieberman JA, Gilmore JH. Cytokine effects on cortical neuron MAP-2 immunoreactivity: implications for schizophrenia. Biol Psychiatry. 2001;50(10):743-749.

[21] Panchuk-Voloshina N, Haugland RP, BishopStewart J, et al. Alexa dyes, a series of new fluorescent dyes that yield exceptionally bright, photostable conjugates. J Histochem Cytochem. 1999;47(9):1179-1188.

[22] Bradford MM. A rapid and sensitive method for the quantitation of microgram quantities of protein utilizing the principle of protein-dye binding. Anal Biochem. 1976;72:248-254.

[23] Laemmli UK. Cleavage of structural proteins during the assembly of the head of bacteriophage T4. $\mathrm{Na}$ ture. 1970;227(5259):680-685.

[24] Van den Bergh G, Clerens S, Cnops L, Vandesande F, Arckens L. Fluorescent two-dimensional difference gel electrophoresis and mass spectrometry identify age-related protein expression differences for the primary visual cortex of kitten and adult cat. J Neurochem. 2003;85(1):193-205.

[25] Wait R, Gianazza E, Eberini I, et al. Proteins of rat serum, urine, and cerebrospinal fluid. VI. Further protein identifications and interstrain comparison. Electrophoresis. 2001;22(14):3043-3052.

[26] Henzel WJ, Billeci TM, Stults JT, Wong SC, Grimley $\mathrm{C}$, Watanabe C. Identifying proteins from twodimensional gels by molecular mass searching of peptide fragments in protein sequence databases. Proc Natl Acad Sci U S A. 1993;90(11):5011-5015.

[27] Zhang W, Chait BT. ProFound: an expert system for protein identification using mass spectrometric peptide mapping information. Anal Chem. 2000;72(11):2482-2489.

[28] Voss T, Haberl P. Observations on the reproducibility and matching efficiency of two-dimensional electrophoresis gels: consequences for comprehensive data analysis. Electrophoresis. 2000;21(16):33453350 .

[29] Zhou G, Li H, DeCamp D, et al. 2D differential in-gel electrophoresis for the identification of esophageal scans cell cancer-specific protein markers. Mol Cell Proteomics. 2002;1(2):117-124.

[30] Stasyk T, Hellman U, Souchelnytskyi S. Optimizing sample preparation for 2-D electrophoresis. Life science News. 2001;9:9-12.

[31] Steinberg TH, Jones LJ, Haugland RP, Singer VL. SYPRO orange and SYPRO red protein gel stains: one-step fluorescent staining of denaturing gels for detection of nanogram levels of protein. Anal Biochem. 1996;239(2):223-237.

[32] Alban A, David SO, Bjorkesten L, et al. A novel experimental design for comparative two-dimensional gel analysis: two-dimensional difference gel electrophoresis incorporating a pooled internal standard. Proteomics. 2003;3(1):36-44.

[33] Parker F, Maurier F, Delumeau I, et al. A RasGTPase-activating protein SH3-domain-binding protein. Mol Cell Biol. 1996;16(6):2561-2569.

[34] Bartling B, Yang JY, Michod D, Widmann C, Lewensohn R, Zhivotovsky B. RasGTPase-activating protein is a target of caspases in spontaneous apoptosis of lung carcinoma cells and in response to etoposide. Carcinogenesis. 2004;25(6):909-921.

[35] Xu R, Xin L, Fan Y, Meng HR, Li ZP, Gan RB. Mouse restin inhibits bovine aortic endothelial cell proliferation and causes cell apoptosis. Acta Biochimica et Biophysica Sinica. 2002;34(2):138-142.

[36] Pereira C, Ferreiro E, Cardoso SM, de Oliveira CR. Cell degeneration induced by amyloid-beta peptides: implications for Alzheimer's disease. J Mol Neurosci. 2004;23(1-2):97-104.

[37] Dho SH, Kwon KS. The Ret finger protein induces apoptosis via its RING finger-B box-coiled-coil motif. J Biol Chem. 2003;278(34):31902-31908.

[38] Diamond MS, Shrestha B, Marri A, Mahan D, Engle M. B cells and antibody play critical roles in the immediate defense of disseminated infection by West Nile encephalitis virus. J Virol. 2003;77(4):25782586.

[39] Sampson BA, Ambrosi C, Charlot A, Reiber K, Veress JF, Armbrustmacher V. The pathology of human West Nile virus infection. Hum Pathol. 2000;31(5):527-531.

[40] Parquet MC, Kumatori A, Hasebe F, Morita K, Igarashi A. West Nile virus-induced bax-dependent apoptosis. FEBS Lett. 2001;500(1-2):17-24.

[41] Yang JS, Ramanathan MP, Muthumani K, et al. Induction of inflammation by West Nile virus capsid through the caspase- 9 apoptotic pathway. Emerg Infect Dis. 2002;8(12):1379-1384. Erratum in: Emerg Infect Dis. 2003;9(3):406. 
[42] Chu JJ, Ng ML. The mechanism of cell death during West Nile virus infection is dependent on initial infectious dose. J Gen Virol. 2003;84(pt 12):33053314.

[43] Mattson MP, Gary DS, Chan SL, Duan W. Perturbed endoplasmic reticulum function, synaptic apoptosis and the pathogenesis of Alzheimer's disease. Biochem Soc Symp. 2001;(67):151-162.

[44] Paschen W, Frandsen A. Endoplasmic reticulum dysfunction-a common denominator for cell injury in acute and degenerative diseases of the brain. J Neurochem. 2001;79(4):719-725.

[45] Tsuji T, Shimohama S, Kimura J, Shimizu K. $\mathrm{m}$-Calpain (calcium-activated neutral proteinase) in Alzheimer's disease brains. Neurosci Lett. 1998;248(2):109-112.

[46] Momburg F, Mullbacher A, Lobigs M. Modulation of transporter associated with antigen processing (TAP)-mediated peptide import into the endoplasmic reticulum by flavivirus infection. J Virol. 2001;75(12):5663-5671. 

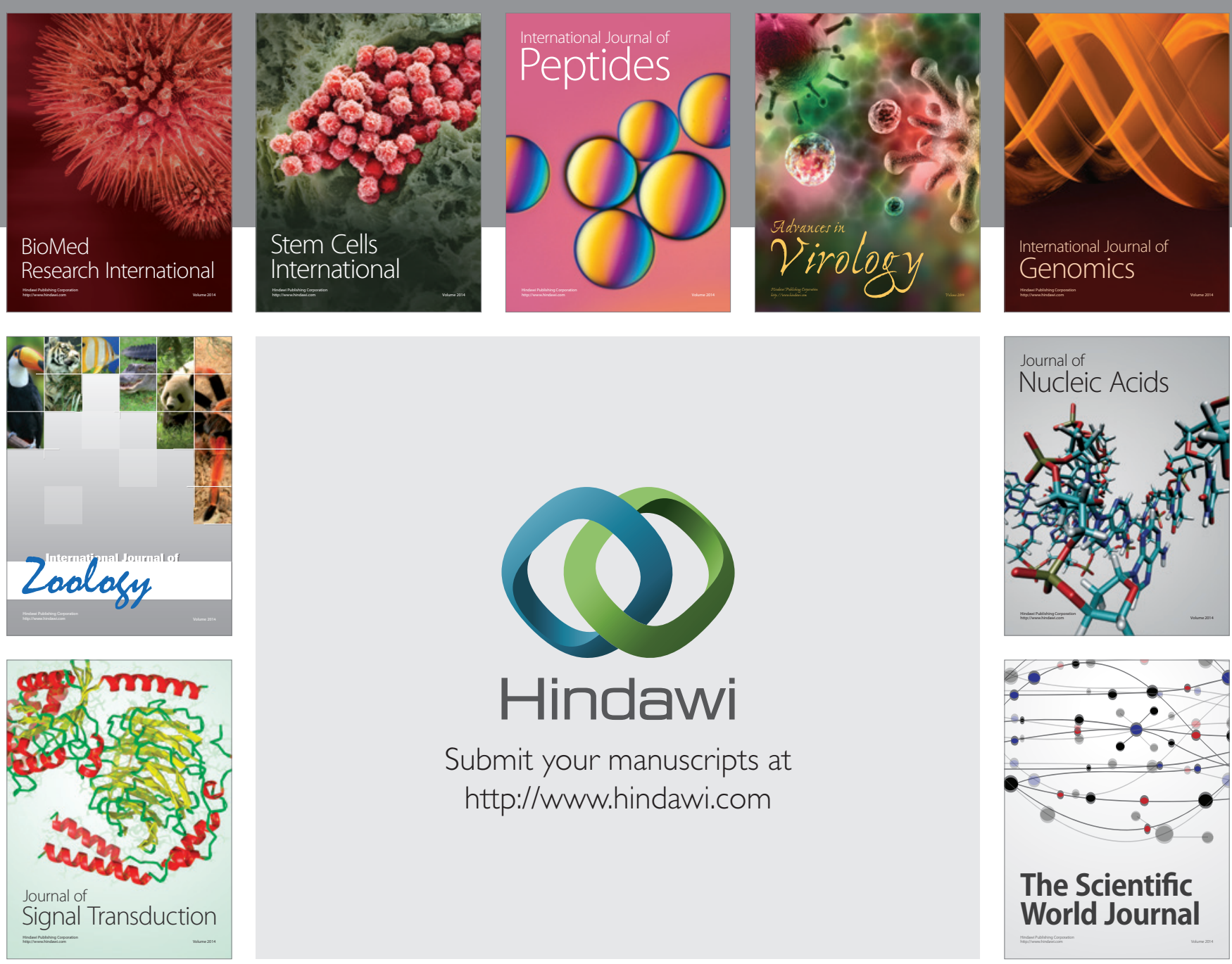

Submit your manuscripts at

http://www.hindawi.com
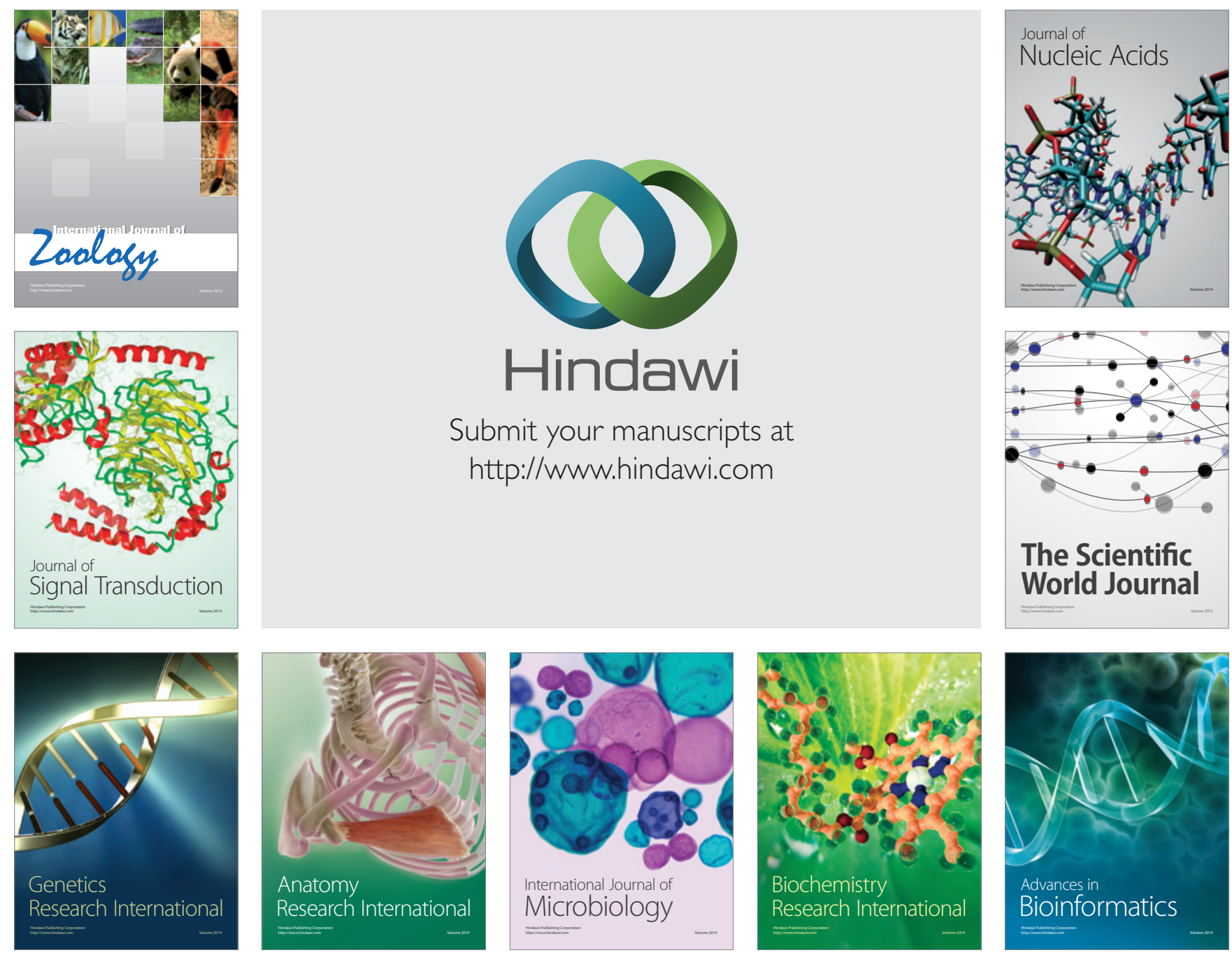

The Scientific World Journal
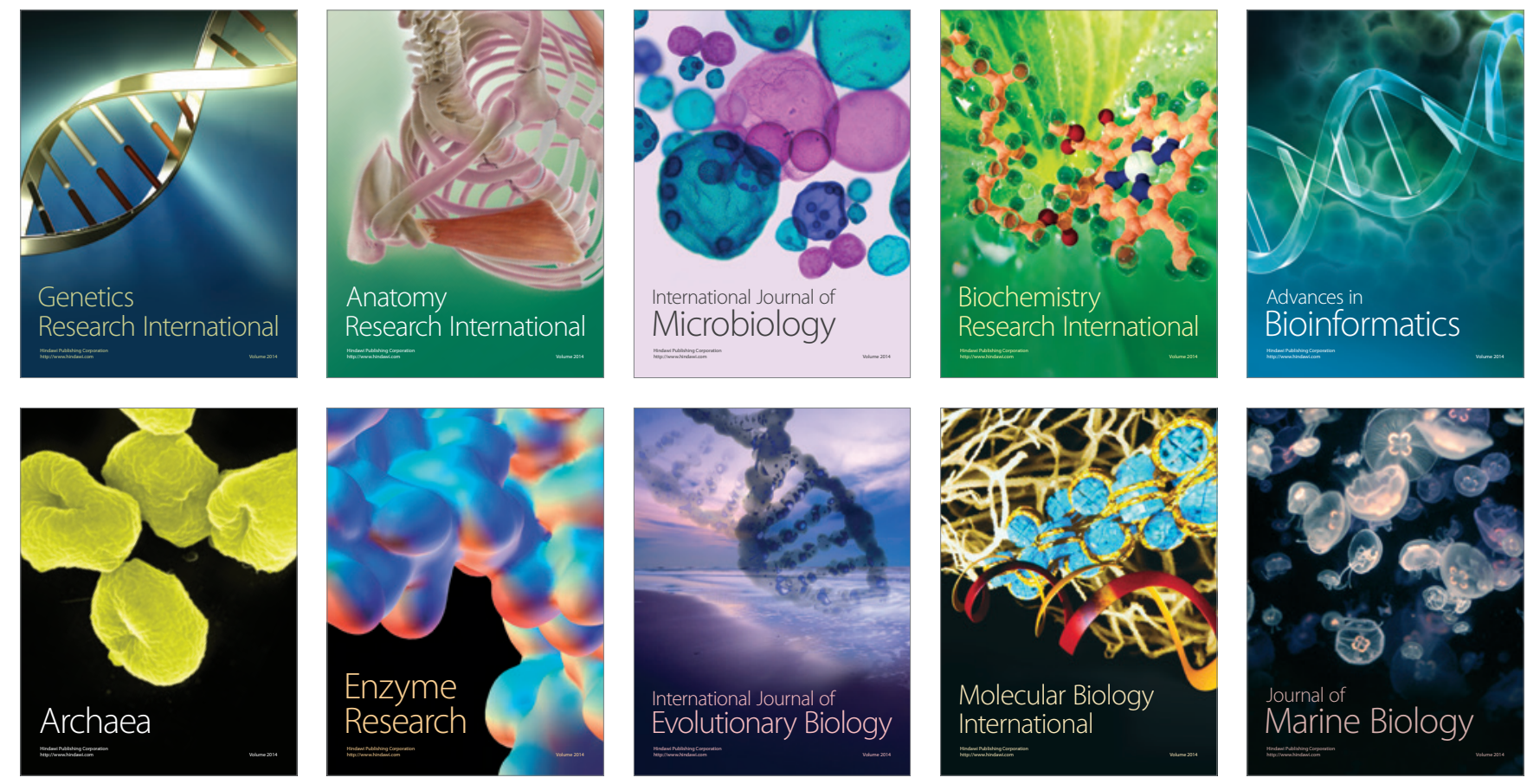